\title{
Translation as communication and auto-communication
}

\author{
Peeter Torop \\ Department of Semiotics, University of Tartu \\ Tiigi St. 78-310, Tartu 50410, Estonia \\ e-mail: peeter.torop@ut.ee
}

\begin{abstract}
If one wants to understand translation, it is necessary to look at all its aspects from the psychological to the ideological. And it is necessary to see the process of translation, on the one hand, as a complex of interlinguistic, intralinguistic, and intersemiotic translations, and on the other hand, as a complex of linguistic, cultural, economic, and ideological activities. Translators work at the boundaries of languages, cultures, and societies. They position themselves between the poles of specificity and adaptation in accordance with the strategies of their translational behaviour. They either preserve the otherness of the other or they transform the other into self. By the same token, they cease to be simple mediators, because in a semiotic sense they are capable of generating new languages for the description of a foreign language, text, or culture, and of renewing a culture or of having an influence on the dialogic capacity of a culture with other cultures as well as with itself. In this way, translators work not only with natural languages but also with metalanguages, languages of description. One of the missions of the translator is to increase the receptivity and dialogic capability of a culture, and through these also the internal variety of that culture. As mediators between languages, translators are important creators of new metalanguages.
\end{abstract}

The status of translation and the translator have changed from one historical era to the next, and at the beginning of the 21 st century we are confronting the need for a complex understanding of both of them. At the core of this complex understanding is the universality of translation. The universality of translation comes from its connections with thought processes. As Juri Lotman affirms, "the elementary act of thinking is translation" (Lotman 2000: 143). And he proceeds to emphasise that "the elementary mechanism of translating is dialogue" 
(Lotman 2000: 143). The irreducibility of dialogue to mere communication in a language common to the dialogue's participants is very important. For Lotman everything begins with the need for dialogue: "[...] the need for dialogue, the dialogic situation, precedes both real dialogue and even the existence of a language in which to conduct it" (Lotman 2000: 143-144).

The need for dialogue can be viewed either at the level of comprehensive theoretical understanding or at the level of the deepseated mechanism of individual behaviour. In the theory of communication, the need for dialogue is tied in a complementary way both to the needs of an audience, which can be studied in the theory of mass communication (McQuail 2000), and to various personal needs (selfunderstanding, enjoyment, escapism) and social needs (knowledge about the world, self-confidence, stability, self-esteem, the strengthening of connections with family and friends) (Fiske 2000: 20). Any form of identity also depends on the need for dialogue. At the core of personal, national, or social identity is the recognition of the boundary between self and other. The boundary not only divides but also unites and thus participates in dialogic processes. To a large extent dialogue within the boundaries depends on dialogue at the boundaries.

Translators work at the boundaries of languages, cultures, and societies. They position themselves between the poles of specificity and adaptation in accordance with the strategies of their translational behaviour. They either preserve the otherness of the other or they transform the other into self. By the same token, they cease to be simple mediators, because in a semiotic sense they are capable of generating new languages for the description of a foreign language, text, or culture, and of renewing a culture or of having an influence on the dialogic capacity of a culture with other cultures as well as with itself. In this way, translators work not only with natural languages but also with metalanguages, languages of description. One of the missions of the translator is to increase the receptivity and dialogic capability of a culture, and through these also the internal variety of that culture. As mediators between languages, translators are important creators of new metalanguages. That is why a contemporary understanding of translation activity presupposes not merely a complex approach - the science of translation also has a need for innovation in the methodology for understanding the translation process. 
What does translation process mean from the methodological viewpoint? As I have put it before elsewhere it is a process that takes place within a translator's mind, but also within language, culture, and society. A cognitive, linguistic, cultural or social process can take place between minds, languages, cultures and societies, but it can also take place within a single mind, language, culture or society. Inevitably, all these processes have to be described in very different description languages (metalanguages), and it would be very difficult to create disciplinary unity in these analyses and descriptions. Therefore, the translation process has to be brought closer to its beginning and to its end. The process of translation happens between two messages or two texts. In the beginning there is the original and at the end there is the translation. The original and the translation are simultaneously both the beginning and the end of the process as well as the cause and the result of the process. (cf. Torop 2007: 353).

Focusing on the process of translation as the main object of research in a science of translation makes it possible to typologize translations as the principle means of transmission of one set of languages-texts-cultures by another. But it does not negate the necessity of also seeing other parameters in the process of translation, in the first place economic and ideological aspects of translation that are in turn associated with professional ethics or with the professional ethics of the translator. The practice of translation is even more complex, and the behaviour of the translator and the quality of his work do not depend solely on his linguistic or literary abilities. The translator is simultaneously a mediator, creator, producer, manager, critic, and sometimes ideologue. All of these roles make up various aspects of cultural behaviour and can be correlated to the entire textual corpus of a culture. An actualization of the various cultural and social roles of the translator reflects the general effort of analysts toward a complex understanding of the phenomenon of translation in the processes of culture.

From the point of view of culture, translation and translation studies are two sides of same phenomenon. Each culture develops in its own way, has its own technological environment and its own traditions of analyzing culture texts. A culture's capacity for analysis reflects its ability to describe and to understand itself. In the process of description and understanding, an important role is played by the multiplicity of texts, by the interrelatedness of communication with 
metacommunication. The multiplicity of texts makes it possible to view communication processes as translation processes. But besides immediate textual transformations, the analysis of these transformations - that is, their translation into various metalanguages has a strong significance in culture. Both in the case of textual transformations and their translations into metalanguages, an important role is performed by the addressees, their ability to recognize the nature of the text at hand, and their readiness to communicate. Just as in translation culture, there is also an infinite retranslation and variation taking place in translation studies. In order to understand different aspects of translation activity, new description languages are constantly being created in translation studies, and the same phenomena are at different times described in different metalanguages. And just as in culture, also in disciplines studying cultural phenomena, variance has its limits and at some point an invariant is needed in order to organize the variance (cf. Sütiste, Torop 2007: 189-190).

\section{Diversity and methodology}

When the diversity of actual translation activity takes a form different from the diversity of scientific approaches to that activity, then one can speak of a methodological crisis, of the hybridization or creolization of scientific languages. A new, comprehensive approach in the science can provide one way out of the given situation. Another way is a review of the history of the discipline and a search there for the lost unity within that discipline. The works of Roman Jakobson provide such a critical point for the history of translation science. Although Jakobson wrote about translation, he was not a translation theorist. He saw translation within the framework of his understanding of the processes of communication, and without this background it is difficult to understand correctly his specific meditations on translation activity.

Jakobson first demonstrated his model of verbal communication (Fig. 1) in 1956 in his article, Metalanguage as a linguistic problem (Jakobson 1985a [1956]). 
CONTEXT
(REFERENTIAL FUNCTION)

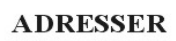

(EMOTIVE F-N)

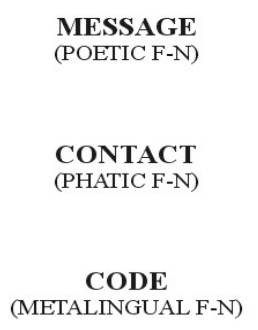

$\underset{\text { (CONATIVE F-N) }}{\text { ADRESSEE }}$

(CONATIVE F-N)

Figure 1. Jakobson's model of communication.

On the one hand, the given model ties its components to various functions of language: "Language must be investigated in all the variety of its functions" (Jakobson 1985a [1956]: 113). On the other hand, along with the various functions of language, it is also important for Jakobson to distinguish two principle levels of language - the level of objective language and the level of metalanguage: "On these two different levels of language the same verbal stock may be used; thus we may speak in English (as metalanguage) about English (as object language) and interpret English words and sentences by means of English synonyms and circumlocutions" (Jakobson 1985a [1956]: 117).

The actualization of the concept of metalanguage as "an innermost linguistic problem" (Jakobson 1985a [1956]: 121), which emerges from Jakobson's logic, is important for an understanding of the psychological as well as linguistic and cultural aspects of the functionality of language.

He begins from the metalinguistic aspect of the linguistic development of a child: "Metalanguage is the vital factor of any verbal development. The interpretation of one linguistic sign through other, in some respects homogeneous, signs of the same language, is a metalingual operation which plays an essential role in child language 
learning" (Jakobson 1985a [1956]: 120). But the development of a child corresponds to the development of an entire culture. For the development of a culture, it is important that the natural language of this culture satisfy all the demands for the description of foreign or of new phenomena and by the same token ensure not only the dialogic capacity but also the creativity and integrity of the culture, its cultural identity: "A constant recourse to metalanguage is indispensable both for a creative assimilation of the mother tongue and for its final mastery" (Jakobson 1985a [1956]: 121). In this way, the abovementioned role of translators as creators of new metalanguages (languages of description and languages of dialogue) is vitally important for a culture. The very concept of metalanguage turns out to be important both at the level of scientific languages and at the level of everyday communication.

If in his 1956 article Jakobson associates the introduction of the concept of metalanguage with the name of Alfred Tarski, then in his article On linguistic aspects of translation, published in 1959 (Jakobson 1971a [1959]), he introduces a new aspect and points to the name of Niels Bohr, who brought out the complementarity of an object-language and its metalanguages. From complementarity comes a more flexible approach to the translatable, since natural language manifests itself as a universal means of communication: "All cognitive experience and its classification is conveyable in any existing language" (Jakobson 1971a [1959]: 263). Complementarity also extends to the definition of types of translation. The concept of interpretation becomes generalized: "We distinguish three ways of interpreting a verbal sign: it may be translated into other signs of the same language, into another language, or into another nonverbal system of symbols" (Jakobson 1971a [1959]: 261). As a result, it is possible to speak of three types of translation: intralingual translation or rewording, interlingual translation or translation proper and intersemiotic translation or transmutation.

If the matter concerns poetic translation or translation of the untranslatable, then Jakobson applies the concept of transposition:

Only creative transposition is possible: either intralingual transposition from one poetic shape into another, or interlingual transposition - from one language into another, or finally intersemiotic transposition - from one system of signs into another, e.g., from verbal art into music, dance, cinema, or painting. (Jakobson 1971a [1959]: 266) 
In sum, alongside objective language and metalanguage arises the complementary pair - interpretation and transposition. This complementarity leads to still another - the complementarity of code-units and of the message as a whole. Jakobson stresses that in inter- and intra-linguistic translation it is usually not possible to speak of a full equivalence between code-units, "while messages may serve as adequate interpretations of alien code-units or messages" (Jakobson 1971a [1959]: 261). The translator works simultaneously with the code-units of languages and with complete messages, with a plan of expression and content, with object- and meta-language, and the division not only into three types of translation but also into two simultaneous translation processes comes precisely from this understanding:

[...] translation from one language into another substitutes messages in one language not for separate code-units but for entire messages in some other language. Such a translation is a reported speech: the translator recodes and transmits a message received from another source. Thus translation involves two equivalent messages in two different codes. (Jakobson 1971a [1959]: 261-262)

\section{Dominant and integration}

The (chrono)logical expression of the next stage in Jakobson's thought is the 1968 article Language in relation to other communication systems (Jakobson 1971d [1968]), two points from which we would like to distinguish in the context of the present article. One of these aspects traces back to an old talk given in 1935 and first published in 1971 - The dominant. The concept of the dominant is significant for the description of translation practice, since underlying various descriptions of the method of a translation or a translator is a determination of that element or level of the text considered most important by the translator. The type of textual integrity also depends on the selection of the dominant for translation, since the authorial dominant underlies the integration of elements in the entire text. Jakobson sums up the research in the following way: "The dominant may be defined as the focusing component of a work of art: it rules, determines, and transforms the remaining components. It is the 
dominant which guarantees the integrity of the structure" (Jakobson 1981 [1935]: 751).

From the point of view of contemporary translation practice and of theoretical or critical thought on this practice, the distinction underlined by Jakobson between communication and information is significant: "[...] we must consistently take into account the decisive difference between communication, which implies a real or alleged addresser, and information whose source cannot be viewed as an addresser by the interpreter of the indications obtained" (Jakobson 1971d [1968]: 703). Thus, translations that deprive the original of authorship, age, nationality, or genre become simply information about the original. The same can be observed on the narrative level, when various points of view in the text are not distinguished, or are mixed-up or reconceptualized (for details see: Levenston, Sonnenschein 1986).

The second aspect of the above-mentioned article flows from the first. The integrating dominant presupposes the existence of an hierarchy in the structure of the message (text). But the process of communication is also viewed hierarchically by Jakobson, so that a comprehension of his model of communication has to rest not so much on a statistical, theoretical basis as on a dynamic, empirical one. Jakobson in his article calls for a consideration of the specificity of each act of communication and correspondingly sees in the act of communication an hierarchy not only of linguistic but also of semiotic functions:

The cardinal functions of language - referential, emotive, conative, phatic, poetic, and metalingual - and their different hierarchy in the diverse types of messages have been outlined and repeatedly discussed. This pragmatic approach to language must lead mutatis mutandis to an analogous study of the other semiotic systems: with which of these or other functions are they endowed, in what combinations and in what hierarchical order? (Jakobson 1971d [1968]: 703)

The linguistic and semiotic aspects of communication are interrelated. An integrated science of communication in Jakobson's opinion contains three disciplinary levels:

1) Study in communication of verbal messages = linguistics; 2) study in communication of any messages = semiotics (communication of verbal messages implied); 3) study in communication = social anthropology jointly with economics (communication of messages implied). (Jakobson 1971c [1967]: 666). 
In another article, Jakobson distinguishes only two sciences from a semantic point of view - a science of verbal signs or linguistics and a science of all possible signs or semiotics (Jakobson 1985b [1974]: 99). Against this background, it is important to remember the universality of the concept of translation. Many processes in the sphere of contiguity between linguistics and semiotics become prominent precisely in translation. We find a direct comparison in the article, Linguistics and communication theory: "The semiotic definition of a symbol's meaning as its translation into other symbols finds an effectual application in the linguistic testing of intra- and interlingual translation" (Jakobson 1971b [1961]: 578). But very often Jakobson makes use of the concepts of verbalized, non-verbalized, and verbalizable, whereby verbalizable signifies translatability into verbal messages (see for example Jakobson 1971c [1967]: 663).

\section{Models of communication and auto-communication}

In respect to the last important aspect for the understanding of the concept of translation in Jakobson's work, it is necessary to point to the interrelation of internal and external communication:

When speaking of language as a communicative tool, one must remember that its primary role, interpersonal communication, which bridges space, is supplemented by a no less important function which may be characterized as intrapersonal communication. [...] While interpersonal communication bridges space, intrapersonal communication proves to be the chief vehicle for bridging time. (Jakobson 1985b [1974]: 98)

Linguistically, this means that problems of interlinguistic and intralinguistic translation largely coincide; psychologically, it means that the mechanisms of communication and auto-communication, or dialogue with other and dialogue with self, also largely coincide. And in the context of Jakobson it follows that we stress once again the homogeneity between internal and external in relation to the person or culture.

It is eminently logical that Jakobson's model of communication has inspired researchers to apply it even to those fields of communication about which Jakobson himself wrote more rarely and with which social anthropologists and economists, in his opinion, should be 
occupied. The transformation of Jakobson's model proposed by I. Even-Zohar appears thus (Fig 2.; Even-Zohar 1990: 31).

CONTEXT
INSTITUTION

ADRESSER
PRODUCER
WRITER
WRITER

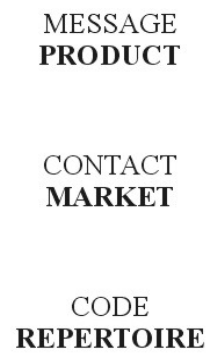

Figure 2. Even-Zohar's transformation of Jakobson's communication model (Even-Zohar 1990: 31).

On the one hand, Even-Zohar was one of the first translation theorists to introduce the concept of the market into the problematic of translation. Along with the market, the publisher as the consumer or as the representative of the consumer of a translation becomes important. The translation itself from an economic point of view becomes a saleable commodity, and the price of this commodity will play a role in its consumption. But the translation as a new text for the receiving culture is often in need of advertisement, or presentation to future readers. This means that along with the new book as a verbal text, various forms of advertisement also enter the culture. In this way, the verbal text receives its visual or audio-visual image. Pedro A. FuertesOlivera and his co-authors also attempt to understand advertising communication on the basis of Jakobson's model (Fig.3; FuertesOlivera et al. 2001: 1293). 


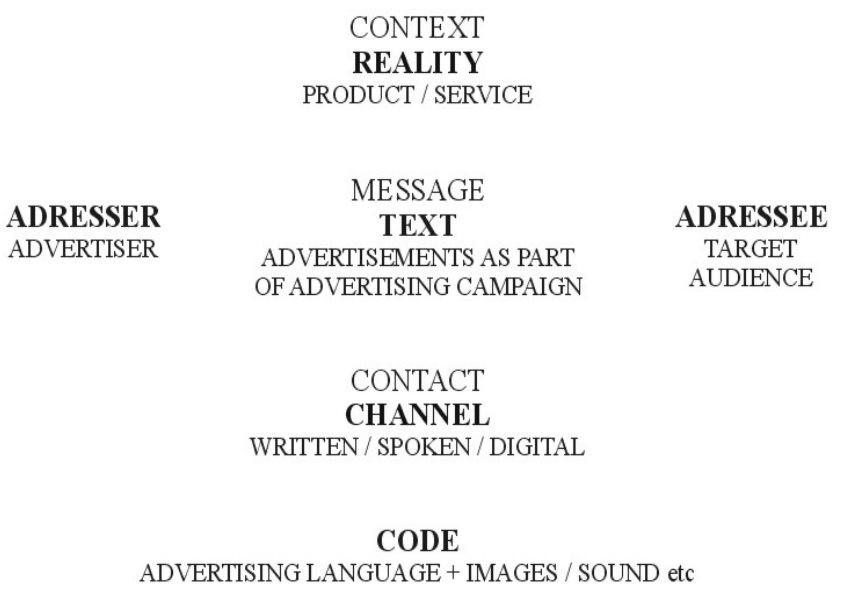

P. A. Fuertes-Olivera

Figure 3. Fuertes-Olivera et al transformation of Jakobson's communication model (Fuertes-Olivera et al. 2001: 1293).

Both models fit Even-Zohar's assertion that if Jakobson's model arises from the speech event, then his own version takes as its basis the socio-semiotic (cultural) event (Even-Zohar 1997: 19). Above we showed the special significance for Jakobson of the metalinguistic function. It is characteristic that also for Even-Zohar the main function is tied to a code, although he has replaced metalanguage with the concept of repertoire. Repertoire depends on both the institution and the market. That is why the concepts of addresser and addressee are conjoined in the concept of repertoire: "There may be a repertoire for being a 'writer', another for being a 'reader', and yet another for 'behaving as one should expect from a literary agent', and so on" (Even-Zohar 1990: 40). In a revised version, the author distinguishes the concepts of active and passive repertoire:

'Repertoire' designates the aggregate of rules and materials which govern both the making and handling, or production and consumption, of any given product. [...] In the case of making, or producing, we can speak of an active operation of a repertoire, or, as an abbreviated term, an active repertoire. In the case of handling, or consuming, on the other hand, we can speak of a 
passive operation, or a passive repertoire. The terms suggested here are for convenience only; the repertoire is neither 'active' nor 'passive', but can be used in different modes in two different circumstances, as described above, namely, in an event where a person produces something, in contradistinction to an event where a person 'deciphers' what others produce. (Even-Zohar 1997: 20)

\section{Ideology, economy and translation}

In the repertoire, economic and ideological problems are conjoined, and against the background of Jakobson's model this means that economic and ideological metalanguages can become actualized in the description of translation. In this case it is appropriate to speak of the inter-discursivity of metalanguages. From the application of this model for the description of advertising communication comes the problem of the intersemiotic nature of metalanguages, since a verbal text can enter a culture and exist there with the support of non-verbal elements of the texts.

There also exists an interesting attempt to unite these two aspects in the concepts of the exogenic and endogenic parameters of translation (les paramètres exogènes, les paramètres endogènes). Entering into the composition of exogenic parameters are economic (la paramètre économique), cultural (la paramètre culturel), and ideological (la paramètre idéologique) parameters (Guidère 2000: 11-30). The composition of endogenic parameters is also three-fold: "d'abord, la différenciation du texte publicitaire au niveau scripturaire; ensuite, sa particularité sur le plan iconographique; enfin, sa spécificité proprement sémiotique" (Guidère 2000: 32). The possibility of differentiating three levels of culture - lexiculture (la "lexiculture"), iconoculture, (l'"iconoculture") and ideoculture (l'"idéoculture") also emerges from the given approach (Guidère 2000: 267-276).

Problems of ideology and economics are difficult to view in isolation, since the concept of the market already combines in itself aspects of both the local and the global market (Apter 2001). The confluence of the economic and the ideological is especially characteristic of

1 " [...] firstly, the differentiation of the advertisement text at the level of composition; then, its peculiarity at the level of iconography; finally, its purely semiotic specificity". 
mass literature. For example, researchers into the translation of mass literature have introduced among other things the concepts of collective translation (team translation), standardization (of theme, language, style, size, weight), the ignoring of authorial idiosyncrasies ("Commercial production ignores the so-called sacredness of the author"), commercial calculations (definite market, deadlines, no revision), selection of texts (reuseability), the repeated publication of old translations (the recycling strategy), marketing strategies (special translation as a euphemism for "contains many cuts"), and pseudotranslations (Malmkjær et al. 2000: 244-247).

Along with neutralized texts in response to the pragmatic laws of mass culture, there are also ideological laws at work in culture. One example of the manifestation of such laws is the emergence within a repertoire (or market) of a particular local culture and a global (mass) culture and the attempt to establish an intermediate market and repertoire, for example, in the European community. Michael Cronin associates this with the concepts of micro-cosmopolitanism and of the negentropic translational perspective:

What we would like to propose is precisely a way of thinking about translation and identity which is grounded in cultural negentropy. This negentropic translational perspective is primarily concerned with the 'emergence of new' cultural forms through translation practice and the way in which translation contributes to and fosters the persistence and development of diversity. (Cronin 2006: 129)

The ideological problems of translation activity have become important both on an empirical and on a theoretical level (compare: Calzada Pérez 2003). The introduction of an author into a culture is already ideologically and politically colored. The channels through which an author enters a culture by means of translation can be divided into two groups - the channel of authorized discourse and the channel of unauthorized discourse. Iona Popa includes in authorized discourses "the exportation channel and the promoted writer, the official channel and the authorised writer, and the patrimonial channel and the canonised writer" (Popa 2006: 206). Adjoined within unauthorized discourses are "the semi-official channel and the banned writer, the parallel channel and the clandestine writer and, finally, the direct and in transit channels and the exiled writer" (Popa 2006: 206). 
The image of the author has an effect not only on the audience but also on the text of the translation. And in this sense translations do not only convey the original — "translations construct or produce their originals" (Hermans 1999: 95). The ideological aspect of translation activity is one of the factors that includes translation within the process of the autocommunication of a culture. Theo Hermans has expanded the boundaries of the understanding of the phenomenon of translation with the help of the concept of ideology:

Paradoxically, this ideological slant is precisely what makes translation interesting as a cultural and historical phenomenon. If it were a matter of technical code-switching only, translation would be as a photocopier. Translation is of interest because it offers first-hand evidence of the prejudice of perception. Cultures, communities and groups construe their sense of self in relation to others and by regulating the channels of contact with the outside world. In other words, the normative apparatus which governs the selection, production and reception of translation, together with the way translations are conceptualized at certain moments, provides us with an index of cultural selfdefinition. It would be only a mild exaggeration to claim that translations tell us more about those who translate and their clients than about the corresponding source texts. (Hermans 1999: 95)

\section{Translation in conflicts}

At the beginning of the present article we wrote about the needs that are satisfied in the process of communication. Translation theory has led in its development to problems of conflict, to problems not only of professional ethics but of the mission of the translator. The mentality of conflict-events for the mass-media audience also depends on translators. On the one hand, translators, like journalists, can turn out to be politically engaged, because they work for a concrete channel of the mass-media, and this also means the representative of a particular position. Mona Baker affirms on this point: "Contemporary wars have to be sold to international and not just domestic audiences, and translation is a major variable influencing the circulation and legitimation of the narratives that sustain these activities" (Baker 2006: 2). On the other hand, the translator, even in the service of a single channel, can have an influence on the mentality of the process of communication, and it is even possible to say that "translation and interpreting are essential for circulating and resisting the narratives 
that create the intellectual and moral environment for violent conflict in the first place, even though the narratives in question may not directly depict conflict or war" (Baker 2006: 2). The role of the translator becomes even more responsible when he is embedded among information sources about events or among journalists who are writing about these events (Palmer 2007: 15). In such a situation of translating an original, the motives and interests both of the source and of the translator come into play.

Of course, it is possible to distinguish between "hard" and "soft" conflicts. Hard conflicts are public events and immediately attract attention to themselves as a lack of information or an error by the translator. Soft conflicts are more latent and do not provoke stormy reactions in response:

In a translational context, soft conflicts often derive from cultural differences in value systems, social conventions and ways of thinking. If the target culture is dominant, then the translator will have to handle the target text carefully to minimise potential problems of miscomprehension, cultural discomfort or resistance on the part of the receiver. Notwithstanding the fact that the source text may appear to be purpose-free, the translating act and target text are purpose-bound, and any translation must fulfill specific functions. Cultural discomfort, uneasiness or misunderstandings and unnecessary hatred or enmity are to be minimized in the target version. (Tang 2007: 141)

In soft conflicts, an interweaving of the ideological and psychological aspects of the translation is unavoidable. For an understanding of the specifics of a translation activity, it is necessary to attempt to discriminate those ideological aspects in the text of the translation that trace back to the editorial board of a particular publication or to the editing of the mass-media. And that makes it appropriate to distinguish the method of the translation from the method of the translator. The method of the translation signifies, on the one hand, the general rules or traditions of translation for a particular type of text, the overall understanding of what makes a high-quality or low-quality translation. It includes on the other hand those social, economic, and ideological norms to which the selection of texts and authors for translation is subordinated in a given society, the editing and the publishing of translations. The method of the translation and the method of the translator can turn out to be in conflict, but they may also come together when the translator works above all for a customer and not for the author of the original. 
For example, depending on the motives of the translator or publisher, one and the same translation text may enter into various repertoires and have various artistic or ideological dominants. Douglas Robinson writes, for example, about translation in a post-colonial context:

Translation plays three sequential but overlapping roles in postcolonial studies: as a channel of colonization, parallel to and connected with education and the overt or covert control of markets and institutions; as a lightning-rod for cultural inequalities continuing after the collapse of colonialism; and as a channel of decolonization. Thus tabulated, three roles mark separate stages in a utopian narrative that informs much of postcolonial studies: from a colonial past taken as harmful; through a complex and conflicted present in which nothing seems easy or clear-cut; to a decolonized future taken as beneficial. (Robinson 1997: 31)

In this way, the mentality of a certain historical era is realized in the translation and may depend both on the translator and on the publisher. It is also possible that the type of publication (book jacket, preface or postscript, illustrations, etc.) is found to be in contradiction with the method of the translator, and in this case it is necessary to speak of the translator's ambivalence.

It is necessary to speak of ambivalence as well in connection with the prestige of the translator's profession in the contemporary world. The American view of the translator's profession is intriguing:

[...] translation professionals have long had an image problem. The portrait of translators derived from most reference books is not flattering - you might find that the Italians coined the catch-phrase traduttore, traditore (translator, traitor). Purchasers of language services are often unaware of the skill needed to recast text in a foreign tongue - the typical response to a translation request in many US corporations used to be: 'Get a secretary to do it'. Translation is often thankless; ask a dozen marketing managers for their experience, and their only memories will be of translation errors. A professional translation does not enjoy praise - it merely avoids criticism. (Sprung 2000: xii)

But a certain ambivalence is observable as well in attempts to define more precisely the limits of the translator's professional ethics in the framework of translation theory. It turns out that there is no single, universal ethic comparable to the Hippocratic oath in medicine. 


\section{Professional ethics}

Andrew Chesterman has made a very serious attempt at a transition from communication to autocommunication, from various ethical models to a unified understanding of the professional ethics and likewise moral identity of the translator. In his opinion, the concepts of the ethics of translation and the translator that exist in translation theory come down to four basic models. The first model is the ethics of representation, at the core of which lies fidelity to the original: "The ethical imperative is to represent the source text, or the source author's intention, accurately, without adding, omitting or changing anything" (Chesterman 2001: 139). The second model is the ethics of service. Here translation is "a commercial service, performed for a client. [...] A prime quality of good translator-servants is thus loyalty; they are loyal above all to the client, but also to the target readers and to the original writer" (Chesterman 2001: 140). The third model is the ethics of communication, within the framework of which "the ethical translator is a mediator working to achieve cross-cultural understanding" (Chesterman 2001: 141). The fourth model is norm-based ethics, the observation of which guarantees the acceptability of the translation. The concept of trust is important here: "[...] if translators behave in predictable, norm-conforming ways, it is easier to trust them - and the profession as a whole" (Chesterman 2001: 142). In the author's opinion, these models are too heterogeneous and rely too little on the qualitative indicators of translation practice.

By way of compensation, Chesterman proposes an ethics of commitment, which rests on a practical evaluation of translation activity: "It is thus also a virtue, supporting the striving for excellence, the wanting to be a good translator" (Chesterman 2001: 147). An awareness of duty is very close to an oath, and Chesterman calls for us to imagine an oath for translators, or a Hieronymic oath. He first proposes nine points for this oath with the following key concepts for the comprehension of the professional ethics of translators: commitment, loyalty to the profession, understanding, truth, clarity, trustworthiness, truthfulness, justice, striving for excellence (Chesterman 2001: 153). Understandably, these keywords are not only bearers of ethical principles - the identity and the self-awareness of translators depend on them as well. Returning to the problem of the dialectical situation, it is possible to say that the enumerated keywords are 
important elements of the language of the dialogue in which translators sense a need or demand, a dialogue which takes place between translators and contemporary society and without which it is difficult to find in society a common understanding on questions of the status of the translator's profession.

\section{Self-description and self-modelling}

Research in the field of translation ethics well illustrates the efforts of one area of culture toward self-understanding and self-description. Self-description is a process of autocommunication, and its result can be a self-modelling that fixes the dominants, the principles of unification, and the generative language of self-description. Lotman defined self-modelling (автомодель) on the basis of a culture as a whole. "Self-modelling is a powerful means for the 'end-regulation' of a culture, attributing to it a systematic unity and largely defining its quality as a reservoir of information" (Lotman 1970: 420). Lotman sees in culture three types of realization of self-modelling: (1) selfmodellings of culture that strive toward a maximal approach to real existing culture; (2) self-modellings that are distinct from the practice of culture and are counted toward the changing of that practice; (3) self-modellings that exist as an ideal self-awareness of the culture distinct from the culture as such (Lotman 1970: 420).

The movement in the direction of a Hieronymic oath is the creation of a self-modelling of the second type, counting toward the change of existing practices. But if we return to the problem, not of the translator, but of the translation, then it is possible to observe behind the dynamic of development two parallel self-modellings and correspondingly two types of metalanguage. And the mixture of these metalanguages illustrates the deep internal bond between processes of thought and metacommunicative processes in culture, and an understanding of this unity traces back to the work of Jakobson. His differentiation of interlinguistic, intralinguistic, and intersemiotic translation is an attempt at the modelling of internal speech. Nikolai Zhinkin has shown the code-transitions within internal speech and the coexistence of verbal and representational codes. He has also extended the results of the analysis of internal speech to the processes of understanding: "understanding, that is, the reception of messages, 
should be viewed as translation from one language into another. Moreover, a language of representation must be one of these languages, since the first, perceived step toward the knowledge of reality is made up of them" (Zhinkin 1998: 161).

It is possible to say that the formation of self-modelling of the first type - that is, maximally reflecting reality - takes place in an understanding of the mechanisms of translation. And it is logically consistent that this model is found still in the process of formation and that translation theory only makes an approach toward this problem. The semiotics of culture clarifies the difficulty of this process, where the comparability of personality and of culture as a collective personality is important. In this way, if the three types of translation outlined by Jakobson reflect the simultaneity of three processes in the psychological process of translation, then the same simultaneous process takes place in culture. Communication is not thinkable without metacommunication, and a translation as a secondary text is only one of many possible metatexts of one and the same original (Popovič 1976). All of these metatexts can be typologized on the basis of Jakobson's classification. And the result is that the entire culture can be conceived of as a process of translation.

The creative and mediating processes operating in culture can be treated as a communicative, metacommunicative and autocommunicative complex. Any creator, while creating his/her work, communicates both with the audience and with himself/herself. The same happens with culture as a collective creator. All the texts of different cultural spheres and all the advertisements, reviews, annotations, translations, studies, screen and stage adaptations, and lectures make up culture as a whole, offering, as an integrated unity, to the society a possibility for self-control and learning, balance between mass and elite culture, but also enforcing certain official or average ways of perception and understanding.

On the one hand, understanding a text means juxtaposing this text's all possible forms of existence in culture. The intensive growth of audiovisual and hypermedial experience of culture has created a new problem also for the analyst. The sign systems of perceptual processes influence understanding more and more, and even for understanding a novel in culture only verbal experience is not sufficient any more. A computer game, a comic strip or a film created on the basis of one text are all part of this text's mental whole in culture, and the analyst cannot ignore this fact. 
On the other hand, all the metatexts that have emerged in culture form a process of a text's translation into culture and recognition in culture. From the point of view of culture as a whole, this process is autocommunicative, since in order to explain a phenomenon, culture searches for description languages that are suitable to it. Being autocommunicative, culture tries to increase the quantity of information in itself, to raise its quality and to change itself through this.

The association of problems of translation simultaneously with communication and metacommunication indicates both the naturalness of the complex approach to translation activity and the multilevelled nature of communication processes in culture. That which on one level of culture manifests itself as a process of communication and a dialogue between addresser and addressee can be seen on a deeper level as the autocommunication of culture and a dialogue of the culture with itself. It is very important axiologically to see both levels, since autocommunicative processes increase the coherence of a culture, support its identity, and do this with the help of selfmodellings. The wealth of a culture is not only in the diversity of texts and events, but also in the diversity of self-modellings of various types in various parts of the culture.

If one wants to understand translation, it is necessary to look at all its aspects from the psychological to the ideological. And it is necessary to see the process of translation, on the one hand, as a complex of interlinguistic, intralinguistic, and intersemiotic translations, and on the other hand, as a complex of linguistic, cultural, economic, and ideological activities. Then it is also easier to approach the translator, perhaps the most important cultural figure of our time. In the logic of the development of translation theory from the concept of fidelity to the original, equivalence, and adequacy, through the concept of acceptability and useability, toward various overarching theories, a communicative understanding of translation has been realized. The analysis of the activity of the translator along with communicative activity and autocommunicative activity opens a new perspective for the understanding of the phenomenon of translation and compels us to study more seriously the axiological and moral problems of translation. $^{2}$

2 Acknowledgement. The author thanks the Centre of Excellence in Cultural Theory and the Estonian Science Foundation Grant no. 5717 for support. 


\section{References}

Apter, Emily 2001. On translation in a global market. Public culture 13(1): 1-12.

Baker, Mona 2006. Translation and Conflict. A Narrative Account. London: Routledge.

Calzada Pérez, María (ed.) 2003. Apropos of Ideology: Translation Studies on Ideology - Ideologies in Translation Studies. Manchester: St. Jerome Publishing.

Chesterman, Andrew 2001. Proposal for a Hieronymic oath. The Translator 7(2): 139-154.

Cronin, Michael 2006. Translation and Identity. London: Routledge.

Even-Zohar, Itamar 1990. Polysystem studies. Poetics Today 11(1): 195-206.

- 1997. Factors and dependencies in culture: A revised outline for polysystem culture research. Canadian Review of Comparative Literature 24(1): 15-34.

Fuertes-Olivera, Pedro A.; Velasco-Sacristán, Marisol; Arribas-Baño, Ascensión; Samaniego-Fernández, Eva 2001. Persuasion and advertising English: Metadiscourse in slogans and headlines. Journal of Pragmatics 33(8): 1291-1307.

Fiske, John 2000. Introduction to Communication Studies. London: Routledge.

Guidère, Mathieu 2000. Publicité et traduction. Paris: L'Harmattan.

Hermans, Theo 1999. Translation in Systems: Descriptive and Systemic Approaches Explained. Manchester: St. Jerome Publishing.

Jakobson, Roman 1971a [1959]. On linguistics aspects of translation. In: Jakobson, Roman, Selected Writings. II. Word and Language. The Hague: Mouton, 260-266.

- 1971b [1961]. Linguistics and communication theory. In: Jakobson, Roman, Selected Writings II: Word and Language. The Hague: Mouton, 570-579.

- 1971c [1967]. Linguistics in relation to other sciences. In: Jakobson, Roman, Selected Writings. II. Word and Language. The Hague: Mouton, 655-695.

- 1971d [1968]. Language in relation to other communication systems. In: Jakobson, Roman, Selected Writings. II. Word and Language. The Hague: Mouton, 697-708.

- 1981 [1935]. The dominant. In: Jakobson, Roman, Selected Writings. III. Poetry of Grammar and Grammar of Poetry. The Hague: Mouton Publishers, 751-756.

- 1985a [1956]. Metalanguage as a linguistic problem. In: Jakobson, Roman, Selected Writings. VII. Contributions to Comparative Mythology. Studies in Linguistics and Philology, 1972-1982. Berlin: Mouton Publishers, 113-121.

- 1985b [1974]. Communication and society. In: Jakobson, Roman, Selected Writings. VII. Contributions to Comparative Mythology. Studies in Linguistics and Philology, 1972-1982. Berlin: Mouton Publishers, 98-100.

Levenston, E. A.; Sonnenschein, Gabriela 1986. The translation of point-of-view in fictional narrative. In: House, Juliane; Blum-Kulka, Shoshana (eds.), Interlingual and Intercultural Communication: Discourse and Cognition in Translation and Second Language Acquisition Studies. Tübingen: Narr, 4959. 
Lotman, Yuri M. 2000. Universe of the Mind. A Semiotic Theory of Culture. Bloomington: Indiana University Press.

Lotman 1970 = Лотман, Юрий 1970. Проблема “обучения культуре” как типологическая характеристика. In: Семиосфера. Санкт-Петербург: Искусство-СПБ, 417-425.

Malmkjær, Kirsten; Milton, John; Smith, Veronica 2000. Translation and mass culture. In: Chesterman, Andrew; Gallardo San Salvador, Natividad; Gambier, Yves (eds.), Translation in Context. Amsterdam: John Benjamins Publishing, 241-259.

McQuail, Denis 2000. McQuail's Mass Communication Theory. London: Sage Publications.

Palmer, Jerry 2007. Interpreting and translation for Western media in Iraq. In: Salama-Carr, Myriam (ed.), Translating and Interpreting Conflict. Amsterdam: Rodopi, 13-27.

Popa, Iona 2006. Translation channels: A primer on politicized literary transfer. Target 18(2): 205-228.

Popovič, Anton 1976. Aspects of metatext. Canadian Review of Comparative Literature 3: 225-235.

Robinson, Douglas 1997. Translation and Empire: Postcolonial Theories Explained. Manchester: St. Jerome Publishing.

Sprung, Robert C. 2000. Introduction. In: Sprung, Robert C. (ed.), Translating Into Success: Cutting-Edge Strategies for Going Multilingual in a Global Age. Amsterdam: John Benjamins, IX-XXI.

Sütiste, Elin; Torop, Peeter 2007. Processual boundaries of translation: Semiotics and translation studies. Semiotica 163(1/4): 187-207.

Tang, Jun 2007. Encounters with cross-cultural conflicts in translation In: SalamaCarr, Myriam (ed.), Translating and Interpreting Conflict. Amsterdam: Rodopi, 135-147.

Torop, Peeter 2007. Methodological remarks on the study of translation and translating. Semiotica 163(1/4): 347-364.

Zhinkin 1998 = Жинкин, Николай 1998. О кодовых переходах во внутренней речи. In: Язык - речь - творчество. Москва: Лабиринт, 146-162.

\section{Перевод как коммуникация и автокоммуникация}

Желая понимать перевод необходимо видеть все его аспекты от психологического до идеологического. И необходимо видеть процесс перевода, с одной стороны, как комплекс интерлингвистических, интралингвистических и интерсемиотических переводов, с другой же стороны как комплекс языковой, культурной, экономической и идеологической деятельности.

На границах языков, культур и обществ работают переводчики. По стратегии своего переводческого поведения они помещаются между 
полюсами спецификации и адаптации. Они или сохраняют чуждость чужого или превращают чужое в свое. Тем самым они перестают быть простыми посредниками, так как в семиотическом смысле они способны генерировать новые языки для описания чужого языка, текста или культуры и обновлять культуру или влиять на диалогоспособность культуры как с другими культурами, так и с самим собой. Таким образом, переводчики работают не только с естественными языками, но и с метаязыками, языками описания. Одна из миссий переводчика увеличивать восприимчивость и диалогоспособность культуры, а через них и внутреннее разнообразие культуры. Будучи посредниками между языками переводчики являются важными создателями новых метаязыков.

\section{Tõlge kui kommunikatsioon ja autokommunikatsioon}

Tõlke kui sellise mõistmiseks on vajalik käsitleda selle kõiki tahke, psühholoogilisest ideoloogiliseni. Ühtlasi tuleb tõlkeprotsessi vaadelda kui keelesisese, keeltevahelise ja intersemiootiliste tõlgete kompleksi ning samaaegselt kui lingvistiliste, kultuuriliste, majanduslike ja ideoloogiliste toimingute kogumit.

Tõlkijad töötavad keelte, kultuuride ja ühiskondade piiridel. Vastavalt oma tõlkekäitumise strateegiatele, asetavad nad end kahe pooluse spetsiifilisuse ja kohandamise - vahele. Nad kas säilitavad Teise teisesuse või muudavad ta Endaks. Sel moel lakkavad nad olemast pelgad vahendajad, kuivõrd semiootilises mõttes on nad võimelised võõra keele, teksti või kultuuri kirjeldamiseks looma uusi keeli ning oma kultuuri uuendama või mõjutama kultuuri võimet teiste kultuuride või iseendaga dialoogi astuda. See tähendab, et tõlkijad ei tööta ainult loomulike keeltega, vaid ka metakeelte, st kirjelduskeeltega. Üks tõlkija missioonidest ongi kultuuri vastuvõtlikkuse ja dialoogivõime ning nende kaudu kultuuri sisemise mitmekesisuse suurendamine. Keelte vahel seisvate vahendajatena on tõlkijad olulised uute metakeelte loojad. 